\title{
Effect of High Pressure Homogenization on Improving the Quality of Milk and Sensory Properties of Yogurt: A Review
}

\author{
R. Massoud, S. Belgheisi, and A. Massoud
}

\begin{abstract}
High pressure processing is one of the advanced technologies to produce safe food, with better quality properties. In recent years, high pressure homogenization is a useful way which has attracted attention to improve the quality, increase shelf life, and maintain nutritional and sensory properties of milk and dairy products. Homogenization is considered a suitable alternative to thermal processes due to the lack of thermal damage. It is also one of the innovative technologies with a positive change in milk particles which leads to enhance the quality, shelf life and popularity of product. In this article, in addition to evaluation of the effect of homogenization on the fat particles, inactivating harmful bacteriophages and spoilage microorganisms, sensory and appearance properties of dairy products, the influence of high pressure homogenization on proteins and the viability of probiotic bacteria in dairy products especially yogurt will be reviewed. These changes result in the development of quality in dairy products and higher consumer's acceptance.
\end{abstract}

Index Terms-High pressure homogenization, microorganism, milk, yogurt, proteins.

\section{INTRODUCTION}

Milk and dairy products are important parts of the human diet, because of their nutritional value and interesting sensory properties. During milk processing, homogenization makes physicochemical changes that affect the characteristics of dairy products and develop their texture and flavor [1]. Homogenization is the mechanical process which reduces the size of the fat globules via pressure and decreases the separation of the creamy part of the product. Homogenization temperature must be over $45^{\circ} \mathrm{C}\left(113^{\circ} \mathrm{F}\right)$, because milk lipase and many microbial lipases are rendered inactive at this temperature [2], [3]. However, the effect of pressure on the size and distribution of fat globules starts at $50{ }^{\circ} \mathrm{C}$. Below this temperature no changes has occurred due to the stability of the fat particles membrane [1].

High pressure homogenization (HPH) is an emerging preservation technology using significantly higher pressures

Manuscript received March 30, 2015; revised May 25, 2015.

R. Massoud is with the Department of Food research, Standard Research Organization, Tehran, P.O. Box1476845711, Iran (e-mail: rm8059@yahoo. com).

S. Belgheisi is with the Faculty of Food Industry and Agriculture, Department of Food Science \& Technology, Standard Research Institute (e-mail: Belgheisi@standard.ac.ir).

A. Massoud is with the Department of Emergency Medicine, Tabriz University of Medical Sciences, Tabriz, Iran (e-mail: armitamassoud@yahoo.com).
(>100 MPa) to improve quality characteristics of dairy products especially yogurt, compared with the conventional process [4], [5]. HPH significantly affects the size of milk fat globules, protein or polysaccharides and modify their functional properties [6]. Furthermore, homogenization influences the dairy products especially yogurt. The small fat globules made by HPH tend to incorporate into the milk proteins, casein and denatured whey, during acidification and gel formation [1]. The viability of probiotics bacteria is enhanced by increasing the homogenization pressure (100 to $300 \mathrm{Mpa})$ due to producing peptides and free amino acids which are necessary for their growth and viability during storage [7], [8]. The accumulation of free fatty acids and the release of amino acids after HPH, sustained better growth of the organisms in yogurts [9]. The HPH treatment also induced higher amount of acids in yogurt. With increasing pressure (100 to 200 bar) the amounts of lactic and acetic acids increased [10]. The effect of HPH on milk and yogurt will be presented in this review.

\section{MILK PROCESSING}

The milk processing consists of following steps: agitation, mixing, and cooling at the farm; clarification, separation, and standardization; pasteurization; homogenization; packaging; all done by sanitation. Clarification includes centrifugation to eliminate sediment, bacteria, and somatic cells from the milk. Also, centrifuges are used to separate cream from skim milk and after that pasteurization (usually $72^{\circ} \mathrm{C}$ for 15 seconds), is applied to destroy harmful microorganisms and pathogens. [1], [3].

\section{A. Homogenization}

Milk is a emulsion of oil in water containing milk fat globule. Milk fat globules prefer to accumulate, according to which the pressure inside large globules is less than inside small globules, so small fat globules tend to join to the large ones. This fact causes the milk fat to come up to the surface of the milk and makes the undesirable separation. To hinder this effect, milk is homogenized [11].

Homogenization, through application of pressure, reduces the milk fat globule size and prevents fat separation from the milk [1]. Homogenization decreases the size of milk fat globules by pumping milk at high pressure through a valve. The process which breaks fat globules to smaller particles (about 3.5 to $1 \mu \mathrm{m}$ ), causes an increase in surface area. Then milk proteins especially casein, cover this newly generated surface of the fat globules. Approximately a minimum 
amount of $0.2 \mathrm{~g}$ of casein $/ \mathrm{g}$ fat is needed to coat the new surface area [3]. Homogenization is a desirable alternative to thermal treatment for producing more natural and fresh food due to consumer demands. This novel technology avoids the harmful effects that heat has on nutritional value, flavor and color of food [5], [12]. The most important purpose of high pressure processing is maintenance of nutritive and sensory properties [13].

\section{B. Types of Homogenization}

As milk is pumped under high pressure, fat globules start to break up. If the pressure drop is through a single valve, the homogenizer is single - stage which is suitable for low-fat or high-viscosity products such as cream and sour cream. On the other hand, the homogenizers that decrease fat particle size in two stages are called dual-stage homogenizers. The first stage pressure, reduces the milk fat globule diameter size approximately less than $1 \mu \mathrm{m}$ and the second stage is designed to break the clusters of fat globules formed in the first stage, to inhibit creaming in milk. Dual stage is effective for high fat content, high solids content, or products in which low viscosity is desired [1], [14], [15]. The second stage in dual stage homogenization enhances denaturation of whey proteins and also increases the free fatty acid content [3], [16].

\section{EFFECT OF HOMOGENIZATION ON MILK}

\section{A. Effect on Microorganisms}

Heat treatments are traditionally used to sterilize or pasteurize food, but simultaneously decrease the sensory and nutritional qualities. As consumers prefer to eat fresh food, alternative technologies such as high pressure homogenization, are investigated to maintain food fresh, safe and healthy during their shelf life [17]. HPH of milk is helpful for bacteriophage [7], [18] and microbial inactivation [5], [19]. Bacteriophages are one of the main agents of failed fermentations in dairy industry [20] and raw milk is the most important source of phages [21]. HPH (>100 MPa) seems to be a useful technological alternatives to pasteurization, which is promising for dairy phages inactivation [5], [22]. The influence of $\mathrm{HPH}$ on phages could be due to the transformation of their protein structure [23]. Table I shows the functional and structural changes in microorganisms during different pressures treatment [14], [17].

TABLE I: THE EFFECT OF DIFFERENT PRESSURES ON MICROORGANISMS

Pressure $(\mathrm{MPa}) \quad$ Structural and functional changes in microorganisms

\begin{tabular}{cl}
\hline 50 & Inhibitation of protein synthesis, Ribosomes decreasing \\
100 & Reversible protein denaturation, Squeeze of gas vacuoles \\
200 & Damage of cell memmbrane, Sign of cell contents leakage \\
300 & Irreversible protein denaturation, Leakage of cell contents \\
\hline
\end{tabular}

The cell viability starts to lose at about $180 \mathrm{MPa}$, and by increasing the pressure, the rate of microbial inactivation increases. High pressures damage the cell membrane and denature proteins [24], [25]. High pressures (>200 MPa) are needed to kill Saccharomyces cerevisiae at $\left(45-60^{\circ} \mathrm{C}\right)$ due to the membrane damage and inactivation of cell metabolism
[26]. HPH treatment is also reported to inactivate milk microorganisms logarithmically such as; L. monocytogenes in milk at $375 \mathrm{MPa}$ and $S$. aureus at $600 \mathrm{MPa}$ [17]. The size and shape of bacteria and also the nature of cell membrane affect their resistance to HPH. The order of microorganism's lethality after high pressure treatment is [8], [26]:

\section{Gram-negative bacteria > Gram-positive bacteria > Yeast $>$ Mold}

Bacterial spores are generally the most resistant microorganism to be inactive and high pressure homogenization is also reported to be able to inactivate spores in high numbers [27] and decrease the total viable count, fungal and coliform counts in milk [2].Ultra High-Pressure Homogenization treatments at $300 \mathrm{MPa}$ were used to milk inoculated with Bacillus cereus, Bacillus licheniformis, Bacillus sporothermodurans, Bacillus coagulans, Geobacillus stearothermophilus and Bacillus subtilis spores to evaluate their inactivation level. Ultra High-Pressure Homogenization conditions at $300 \mathrm{MPa}$ with $75^{\circ} \mathrm{C}$ were capable of spore inactivation of about 5 $\log \mathrm{CFU} / \mathrm{mL}$. B.subtilis and G. stearothermophilus showed higher resistance to the Ultra High-Pressure Homogenization treatments than the other microorganisms [27].

The viability of probiotics increased by increasing the homogenization pressure (60 to $100 \mathrm{Mpa}$ ) due to producing free amino acids and peptides which are necessary for their growth and viability during storage [5], [7].

\section{B. Effect on Proteins}

During HPH, milk fat globule membranes are influenced, and a new surface area is created. Milk proteins, especially casein, cover the entire available surface and act as a natural emulsifying agent. [4], [12]. HPH causes the break of the casein micelles into smaller fragments and an increase in the calcium phosphate and caseins content in the serum phase. Also, after HPH treatment, the denaturation of milk and whey proteins, especially $\beta$-lactoglobulin, $\alpha$-lactalbumin and several immunoglobulins takes place [28], [29]. $\alpha-$ lactalbumin is generally more resistant to $\mathrm{HPH}$ than $\beta$-lactoglobulin and its changes start at $200 \mathrm{MPa}$ [30]. HPH causes proteins structural rearrangement by enhancing the exposure of their hydrophobic regions [5]. The structural changes in milk proteins strongly relate to the pressure treatment. The denaturation of proteins at $100 \mathrm{MPa}$ is reversible whereas the irreversible denaturation of proteins occurs above $200 \mathrm{MPa}$ [31]. The homogenization pressure could induce some conformational changes in whey proteins and caseins, which could increase their susceptibility to proteolysis, and therefore the availability of free amino acids, which are used by probiotic bacteria directly; and so, their viability increased [7]. Whey proteins are structurly stable and cannot interact with caseins, fat globules or calcium ions in their native form. After homogenization denatured whey proteins can bind with fat particles and caseins. All these changes are important and during yogurt production [1].

Homogenization of milk combined with heat treatment, causes transformation in protein compound, secondary structural loss, especially $\beta$-sheet and $\alpha$-helix, and reduction 
in the contact surface of tertiary structure [31].

The secondary and tertiary structural stability of whey protein are directly affected by pressure. The following order shows their stability level [15], [31]:

\section{$\mathrm{HTST}^{1}$, Homogenized > homogenized and pasteurized > $\mathrm{HPH}$}

\section{Effect on Sensory Properties of Dairy Products}

The appearance of dairy products is considered as a measure of quality by consumers. The white color of milk is due to the scattering of light by the fat particles, proteins and calcium phosphate. After homogenization, fat globules and casein micelles get smaller, therefore homogenized products appear whiter and more desirable [3]. The fermented milk texture strongly relates to the network made by casein and fat globules [32]. The size of fat and protein particles, directly affects the protein matrix of fermented milks, so the texture of dairy products is significantly influenced by $\mathrm{HPH}$ treatment [7]. HPH is also used for the production of fermented dairy products with specific aromatic profiles such as diacetyl and acetaldehyde that results in better taste and flavor [1], [7].

Totally improved sensorial properties of high pressure homogenized milk, whiter color, better flavor, viscosity and stability increase the quality of dairy products such as cheeses and yogurt [7].

\section{Effect on Yogurt Properties}

Fermented dairy products are more desirable and also have higher nutritional value than milk [1]. Yogurt is the most popular dairy product due to its appealing sensory properties. Yogurt is produced from milk mostly with the addition of some derivative of milk, such as whey concentrates, skim milk powder, caseinates or cream with a gel texture which is caused by the coagulation of the milk proteins, due to the lactic acid produced by bacteria cultures. [3]. Yogurt production comprises many processes which milk homogenization is the main one among all [2]. For yogurt manufacture, milk is normally homogenized (15 to $20 \mathrm{MPa}$ ) and heat-treated to decrease microbial load and whey separation during storage, to increase the yogurt consistency, stability and texture [32], [33].

$\mathrm{HPH}$ is an innovative method in yogurt processing which improves the coagulation characteristics of milk due to making the balance between soluble and insoluble forms of nitrogen, calcium and phosphorus, therefore more desirable yogurt is produced [34]-[36] Additionally, HPH treatment improves the rheological properties such as viscosity, firmness and syneresis resistance of gels [7], [28], increases the viability of $L$. delbrueckii and $S$. thermophilus during storage of yogurt in refrigerator and decreases the risks of post-acidification [37], [38]. Increasing viscosity index and gel firmness with pressure can be illustrated with the casein-fat or casein-casein interactions and the denatured whey proteins binding with water and fat which are caused by HPH treatment [34], [39], [40]. Also decreasing soluble protein content, which is connected with the production of

${ }^{1}$ High Temperature Short Time. insoluble high molecular weight coaggregates due to whey protein denaturation during HPH treatment, enhance viscosity [28]. The usage of HPH in acidified milk gels, like yogurt improves the firmness and texture, and increases the water holding capacity and decreases syneresis in [27]. The combination of homogenization and thermal processing increase yogurt viscosity and lower gelation times [1].

After HPH, some branched-chain amino acids are produced which make a proper situation for growth of $S$. thermophilus and L. delbrueckii in yogurt [4], [37]. The counts of L. delbruecki and S. thermophilus were observed in yoghurts from milk treated at 200 and $300 \mathrm{MPa}$ and the results showed the higher microbial counts and so higher activities in yoghurts treated at $300 \mathrm{MPa}$, due to the synthesis of some useful compounds during HPH [4].

Fermented dairy products, and especially yogurt, are noticable carriers for probiotics to go through the human digestive system and cause many health advantages including anti-carcinogenic effects and anti-infection properties, immune system stimulation, cholesterol reduction, alleviation of lactose intolerance symptoms, and nutritional enhancements [33], [37]. The minimum necessary concentration of probiotic bacteria to cause beneficial result has been generally accepted as $10^{6}$ viable cells/g of product at the moment the product is consumed [9], [37].

During homogenization, shear stress and temprature cause reduction in milk fat globule size, disintegration of the casein micelles into smaller particles and also denaturation of several whey proteins occurs, in particular $\beta$-lactoglobulin. So that these remains can be used easier by probiotic bacteria to continue to live and grow in yogurt [1]. Increasing homogenization temperature $\left(50\right.$ to $\left.70^{\circ} \mathrm{C}\right)$ and pressure $(100$ to 200 Bar) simultaneously, have a noticeable effect on the sensory properties and viability of probiotic bacteria in the yogurt during storage due to producing free amino acids and free fatty acids which are necessary for their growth and viability by HPH processing [41].

Investigating the amount of non-volatile acids (lactic or pyruvic) and volatile acids (butyric or acetic) in yoghurts made from high pressure homogenized milk (200 or $300 \mathrm{MPa}$ ) showed that all four acids were increased and pyruvic acid was much higher in the yogurts than others [4]. It is reported that the accumulation of acids like lactic and acetic resulted in decreasing $\mathrm{pH}$ and increasing acidity value [42], [43]. Acetic and lactic acids are known to be utilized during the fermentation process and accumulate over time during storage in yogurt. The amounts of these acids are higher in yogurt produced by HPH due to the higher activity and viability of probiotic bacteria [10], [44].

\section{CONCLUSION}

High pressure homogenization is one of the non-thermal processing which is applied to produce safe food with high nutritional values and desirable sensory properties. It is the most frequently used alternative technologies due to its suitability for solid and liquid food applications. This novel method causes some remarkable changes such as: inactivating harmful bacteriophages and spoilage 
microorganisms, breaking up the fat globules and denaturation of proteins by using pressure rather than heat. These conversions result in the development of quality in dairy products and higher consumer's acceptance. Homogenization also improves the viability of probiotic bacteria in dairy products especially yogurt, during refrigerated storage due to the effective changes in the milk.

\section{REFERENCES}

[1] P. Sfakianakis and C. Tzia, "Conventional and innovative processing of milk for yogurt manufacture, development of texture and flavor: A review," Foods, vol. 3, pp. 176-193, 2014.

[2] O. A. Olorunnisomo, T. O. Ososanya, and O. Y. Adedeji, "Homogenization of milk and effect on sensory and physic-chemical properties of yoghurt," AFR. J. Food Sci., vol. 8, pp. 465-470, 2014.

[3] R. C. Chandan and A. Kilara, Dairy Ingredients for Food Processing, $1^{\text {st }}$ ed. Iowa, U.S.A: Wiley- Blackwell, 2011, ch. 1, 3 and 4, pp. 3-123.

[4] M. Serra, A. J. Trujillo, B. Guamis, and V. Ferragut, "Flavour profiles and survival of starter cultures of yogurt produced from high-pressure homogenized milk," Int. Dairy J., vol. 19, pp. 100-106, 2009.

[5] R. Capra, F. Patrignani, A. Quiberoni, J. Reinheimer, M. Lanciotti, and M. Guerzoni, "Effect of high pressure homogenization on lactic acid bacteria phages and probiotic bacteria phages," Int.l Dairy J., vol. 19, pp. 336-341, 2009.

[6] S. Sandra and D. G. Dalgleish, "Effects of ultra-high-pressure homogenization and heating on structural properties of casein micelles in reconstituted skim milk powder," Int. Dairy J., vol. 15, pp. 1095-1104, 2005.

[7] F. Patrignani, L. Iucci, R. Lanciotti, M. Vallicelli, J. M. Maina, W. H. Holzapfel, and M. Guerzoni, "Effect of high-pressure homogenization, nonfat milk solids, and milkfat on the technological performance of a functional strain for the production of probiotic fermented milks," $J$ Dairy Sci., vol. 90, pp. 4513-4523, 2007.

[8] P. Burns, F. Patrignani, D. Serrazanetti, G. C. Vinderola, and J. A. Reinheimer, "Probiotic crescenza cheese containing Lactobacillus casei and Lactobacillus acidophilus manufactured with high-pressure homogenized milk," J. Dairy Sci., vol. 91, pp. 500-512, 2008.

[9] O. N. Donkor, S. L. I. Nilmini, P. Stolic, T. Vasiljevic, and N. P. Shah, "Survival and activity of selected probiotic organisms in set-type yoghurt during cold storage," Int. Dairy J., vol.17, pp. 657-665, 2007.

[10] R. Massoud, V. Fadaei, and K. Khosravi-Darani, "The effect of homogenization pressure and stages on the amounts of Lactic and Acetic acids of probiotic yoghurt," AFB, vol.1, pp. 25-29, 2014.

[11] P. P. Fox, "Fat globules in milk," Encyclopedia of Dairy Sciences, $2^{\text {nd }}$ ed. London, UK, Elsevier, 2011, pp. 1564-1548.

[12] A. I. V. Ross, M. W. Griffiths, G. S. Mittal, and H. C. Deeth, "Combining nonthermal technologies to control foodborne microorganisms,” Int. J. Food Microb., vol. 89, pp. 125-138, 2003.

[13] S. Karlović, T. Bosiljkov, M. Brnčić, D. Semenski, F. Dujmić, B. Tripalo, and D. Ježeka, "Reducing fat globules particle-size in goa milk: Ultrasound and high hydrostatic pressures approach," Chem. Biochem. Eng. Q., vol. 28, pp. 499-507, 2014.

[14] R. K. Robinson, Dairy Microbiology Handbook, $3^{\text {rd }}$ ed. New York, U.S.A.: John Wiley and Sons, 2002, ch. 1, pp. 2-40.

[15] D. W. Sun, Thermal Food Processing, $1^{\text {st }}$ ed. New York, U.S.A.: Taylor \& Francis, 2006, ch. 17, pp. 527-567.

[16] A. Thompson, M. Boland, and S. Harjinder, Milk Proteins: From Expression to Food, $1^{\text {st }}$ ed. New York, U.S.A.: Elsevier, 2009, ch. 7, pp. 205-227.

[17] B. H. Lado and A. E. Yousef, "Alternative food-preservation technologies: efficacy and mechanisms," Microbes and Infection, vol. 4, pp. 433-440, 2002.

[18] M. Thiebaud, E. Dumay, L. Picart, J. P. Guiraud, and J. C. Cheftel, "High pressure homogenization of raw bovine milk. Effects on fat globule size distribution and microbial inactivation," Int. Dairy J., vol. 13, pp. 427-439, 2003.

[19] J. F. Vachon, E. E. Kheadr, J. Giasson, P. Paquin, and I. Fliss, "Inactivation of foodborne pathogens in milk using dynamic high pressure," J. Food Protect., vol. 65, pp. 345-352, 2002.

[20] H. A. Heap and J. T. Harnett, Bacteriophage in the Dairy Industry, H. Roginski, J. W. Fuquay, P. F. Fox, Ed. Academic Press Elsevier Science, Cornwall, UK, 2002, pp. 136-141.

[21] H. Neve, "Bacteriophage," in Dairy Starter Cultures, T. M. Cogan, J. P. Accolas, Eds. VCH Publishers, Inc., New York, NY, USA, 1996, pp. 157-190.

[22] V. Suárez, S. Moineau, J. Reinheimer, and A. Quiberoni, "Argentinean Lactococcus lactis bacteriophages: Genetic characterization and adsorption studies," J. Appl. Microbiol., vol. 104, pp. 371-379, 2008.

[23] S. F. Grove, A. Lee, T. Lewis, C. M. Stewart, H. Chen, and D. G Hoover, "Inactivation of foodborne viruses of significance by high pressure and other processes," J. Food Protec., vol. 69, pp. 957-968, 2006.

[24] D. G. Hoover, C. Metrick, A. M. Papineau, D. F. Farkas, and D. Knorr, "Biological effects of high hydrostatic pressure on food microorganisms," Food Technol., vol. 43, pp. 99-107, 1989.

[25] K. J. A. Hauben, D. H. Bartlett, C. C. F. Soontjens, K. Cornelis, E. Y. Wuytack, and C. W. Michiels, "Escherichia coli mutants resistant to inactivation by high hydrostatic pressure," Appl. Environ. Microbiol., vol. 63 , pp. 945-950, 1997.

[26] G. Arroyo, P. D. Sanz, and G. Prestamo, “ Response to high-pressure, low-temperature treatment in vegetables: Determination of survival rates of microbial populations using flow cytometry and detection of peroxidase activity using confocal microscopy," J. Appl. Microbiol., vol. 86 , pp. 544-556, 1999.

[27] G. G. A. Espejoa, M. M. Hernández-Herreroa, B. Juana, and A. J. Trujilloa, "Inactivation of Bacillus spores inoculation in milk by ultra high pressure homogenization," Food Microbiol., vol. 44, pp. 204-210, 2014.

[28] A. J. Trujillo, M. Capellas, J. Saldo, R. Gervilla, and B. Guamis, "Applications of high-hydrostatic pressure on milk and dairy products: A review," Innov. Food Sci. Emerg. Technol., vol. 4, pp. 295-307, 2002.

[29] P. Sfakianakis, E. Topakas, and C. Tzia, "Comparative study on high-intensity ultrasound and pressure milk homogenization: Effect on the kinetics of yogurt fermentation process," Food and Bioprocess Technol., vol. 8, pp. 548-557, 2014.

[30] H. A. Patel, H. Singh, S. Anema, and L. K. Creamer, "Effects of heat and high hydrostatic pressure treatments on disulfide bonding interchanges among the proteins in skim milk," J Agric Food Chem., vol. 54, pp. 3409-3420. May 2006.

[31] P. X. Qi, D. Ren, Y. Xiao, and P. M. Tomasula, "Effect of homogenization and pasteurization on the structure and stability of whey protein in milk," J. Dairy Sci., vol. 15, pp. 22-30, Feb 2015.

[32] J. A. Lucey, "Cultured dairy products: An overview of their gelation and texture properties," Int. J. Dairy Technol., vol. 57, pp. 77-84, 2004.

[33] A. Y. Tamime and R. K. Robinson, Yoghurt Science and Technology, 1st ed. Cambridge, UK: Woodhead Publishing, 2007, ch. 5, pp. 241250.

[34] E. E. Kheadr, J. F. Vachon, P. Paquin, and I. Fliss, "Effect of dynamic pressure on microbial, rheological and microstructural quality of Cheddar cheese," Int. Dairy J., vol. 12, pp. 435-446, 2002.

[35] R. Lanciotti, F. Patrignani, L. Iucci, P. Saracino, and M. E. Guerzoni, "Potential of high pressure homogenization in the control and enhancement of proteolytic and fermentative activities of some Lactobacillus species," Food Chem., vol. 102, pp. 542-550, 2007.

[36] M. Serra, A. J. Trujillo, P. D. Jaramillo, B. Guamis, and V. Ferragut, "Ultra-high pressure homogenization-induced changes in skim milk: impact on acid coagulation properties," J. Dairy Res., vol. 75, pp. 69-75, 2008.

[37] A. G. Da Cruz, J. A. F. Faria, S. M. I. Saad, H. M. A. Bolini, A. S. Sant'Ana, and M. Cristianini, "High pressure processing and pulsed electric fields: Potential use in probiotic dairy foods processing," Trends Food Sci. Technol., vol. 21, pp. 483-493, 2010.

[38] G. E. Gardiner, R. P. Ross, P. M. Kelly, and C. Stanton, "Microbiology of therapeutic milks," in Dairy Microbiology Handbook, R. K Robinson, Ed. New York: John Wiley \& Sons, 2002, ch. 8, pp. 431-478.

[39] R. Lanciotti, L. Vannini, L. Pittia, and M. E. Guerzoni, "Suitability of high-dynamicpressure-treatedmilk for the production of yogurt," Food Microbiology, vol. 21, pp. 753-760, 2004.

[40] N. P. Shah, "Functional cultures and health benefits," Int. Dairy J., vol. 17, pp.1262-1277, 2007.

[41] R. Massoud, V. Fadaei, and K. Khosravi-Darani, "The effect of homogenization pressure and stages on viability of probiotic bacteria and sensory properties of probiotic yogurt," EJFPP, vol. 6, pp. 37-52, 2014 [In Persian].

[42] N. P. Shah, "Probiotic bacteria: Selective enumeration and survival in dairy foods," J. Dairy Sci., vol. 83, pp. 894-907, 2000.

[43] R. I. Dave, "Viability of yoghurt and probiotic bacteria in yoghurts made from commercial starter cultures," Int. Dairy J., vol. 7, pp. 31-41, 1997.

[44] M. Gueimonde, L. Alonso, T. Delgado, J. C. Bada-Gancedo, and C. Reyes-Gavilan, "Quality of yoghurt made from refrigerated and CO2-treated milk," Food Res. Int., vol. 36 , pp. 43-48, 2003. 


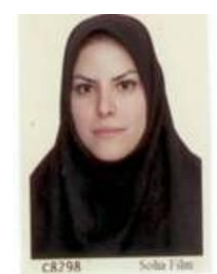

R. Massoud was born in Iran in 1980. She studied for BSc degree in food science and technology in Iran (Tehran) at Azad University Science and Research Branch in 2004 and after that she received her MSc of food science and technology degree at the same university. She passed MSc with good grade as a top student.

Now, she is working at Standard Research Organization in Iran as a faculty member of Food Science and Technology Department. Ms. Ramona Massoud is a member of Food Science Society in Iran and APCBEES.

S. Belgheisi was born in Iran in 1982. She studied for BSc degree in food science and technology in Iran (Tehran) at Shahid Beheshti Medical Science of University in 2006 and immediately after that she received her MSc of food science and technology degree at the same university. She passed MSc with good grade as a top student.

Now, she is working at Standard Research Center in Iran as a faculty member of Food Science and Technology Department.

Ms. Saba Belgheisi is a member of Food Science Society in Iran and APCBEES.

A. Massoud was born in Iran in 1982. She studied GP in Iran (Tehran) at the Department of Medicine Azad university in 2007 and she is now studying as a resident at Department of Emergency Medicine at Tabriz University of Medical Sciences, Tabriz, Iran. 